\title{
Nesting biology of the Hooded Crow Corvus corone cornix in a mixed residential-agricultural area in southern Sweden
}

\author{
Gråkråkans Corvus corone cornix häckningsbiologi i en blandmiljö av bebyggelse \\ och jordbruk i södra Sverige
}

REBECCA HESSEL \& JOHAN ELMBERG

\begin{abstract}
We studied 11 active and 29 old nests of Hooded Crows Corvus corone cornix in a mixed residential-farmland landscape $\left(3.6 \mathrm{~km}^{2}\right)$ in southern Sweden in 2009. The density of active nests was $3.06 / \mathrm{km}^{2}$ land area and $7.33 / \mathrm{km}^{2}$ forest area. Thirty-eight nests were in pinedominated forest and two in private gardens. All nests (active and old) were in pine trees Pinus sylvestris, and sample plots around nest trees had the following characteristics (means): 350 tree stems/hectare, 1487 bushes/ hectare, and canopy cover $8 \%$. Distance to the nearest active Crow nest averaged $234 \mathrm{~m}$, but variation was large. Mean distance from nests to nearest forest edge was 19 $\mathrm{m}$ and to the nearest inhabited building $68 \mathrm{~m}$. Nests were

placed near the tree top (mean height $11 \mathrm{~m}$ ) in all cardinal directions but with a significant bias towards the south. Seven out of $11(64 \%)$ active nests produced fledglings (mean 1.2 nestling/successful nest). Breeding success was higher in nests that were close to another crow nest. Compared with previous studies, hatching success was high but final fledgling production was low.

Rebecca Hessel, Vemmenhögsgatan 44, S-291 37 Kristianstad, Sweden.

E-mail: kakadua_rebecca@hotmail.com

Johan Elmberg, Aquatic biology and chemistry,

Kristianstad University, S-291 88 Kristianstad, Sweden.
\end{abstract}

Received 1 July 2010, Accepted 4 October, Editor: S. Svensson

\section{Introduction}

The Hooded Crow Corvus corone cornix is a common and conspicuous breeding bird over large parts of Europe, inhabiting a range of habitats from the Mediterranean to the Arctic Ocean (Hagemeijer \& Blair 1997). Although there is a lot of older and faunistic information about the species (e.g. Cramp \& Simmons 1977, Glutz von Blotzheim 1990), surprisingly little recent information is found in the indexed scientific literature. Out of 105 hits in the Biological Sciences data base (18 May 2010, search string "(Hooded crow) OR Corvus AND cornix", years 1982-2010), only a handful concerns its breeding biology, and only two such papers have appeared in the last 15 years (Smedshaug et al. 2002, Zduniak \& Antczak 2003). The paucity of recent data about breeding biology may be of concern, as the Hooded Crow has experienced significant and hitherto unexplained population declines in recent decades in some countries (for example Sweden and Finland; Ottvall et al. 2009, Finnish Museum of Natural History 2010).

Although the Hooded Crow breeds throughout
Northern Europe and in almost all habitats, landscapes with a mix of forest, farmland and residential areas can be termed as typical breeding habitat generally holding strong populations (e.g. Møller 1983, Hagemeijer \& Blair 1997). We here report on a study on breeding Hooded Crows in a landscape of this type, addressing the following questions: (1) What is the density of nesting territories? (2) What is the preferred nesting habitat? (3) What do nesting territories look like? (4) Which is the preferred species of nesting tree? (5) What are the characteristics of the nearest surroundings of nest trees? (6) When do eggs hatch? (7) When do chicks leave the nest?

\section{Methods}

Study area

This study was carried out in 2009 in the northwestern part of Åhus municipality (Scania, Sweden). The study area is $3.6 \mathrm{~km}^{2}$, squarish in shape and bordered by Flötövägen in the south, road \#118 in the east, Pallers väg in the north and Hornavägen in the west (corner coordinates: NW: $55^{\circ} 57.039^{\prime} \mathrm{N}$, 
$14^{\circ} 15.620^{\prime} \mathrm{E}$; NE: $55^{\circ} 56.644^{\prime} \mathrm{N}, 14^{\circ} 17.088^{\prime} \mathrm{E}$; SE: $55^{\circ} 55.784^{\prime} \mathrm{N}, \quad 1^{\circ} 17.397 ' \mathrm{E} ; \quad \mathrm{SW}: 5^{\circ} 56.159^{\prime} \mathrm{N}$, $14^{\circ} 14.631$ 'E). There are three distinct habitats: (1) residential areas $\left(1 \mathrm{~km}^{2}\right),(2)$ open steppe-type sandy grasslands $\left(1 \mathrm{~km}^{2}\right)$, and (3) planted pine forest $\left(1.5 \mathrm{~km}^{2}\right)$. Residential areas comprise low family homes and their gardens. Grasslands are either grazed by horses or fallow fields too dry to cultivate. Pine Pinus silvestris forests are fairly mature and planted monocultures, but do in places support clusters of spruce Picea abies, silver birch Betula pendula, mountain ash Sorbus aucuparia, oak Quercus robur, beech Fagus sylvatica, and poplar Populus spp. Parts of the forest have an understorey mainly comprising raspberry Rubus idaeus, blackberry Rubus spp., elderberry Sambucus nigra, red elderberry Sambucus racemosa, and hawthorn Crataegus spp.. The study area is flat, $5-10 \mathrm{~m}$ above sea level, and enjoys a temperate climate with oceanic influence (growing season April-November, mean annual snow cover $<1$ month).

\section{Mapping of nests and their surroundings}

The study area was visited five times in FebruaryMarch and weekly (in some weeks daily) during the brooding, hatching and fledging periods in April through the first week of June. Active territories, active nests and old nests were mapped in all areas supporting trees (residential areas and forests). All roads and paths in the residential areas were visited, and all forest habitat was covered by foot using parallel line transects $50 \mathrm{~m}$ apart. Seventy-five old nests were found during the early visits (FebruaryMarch), and 29 of them were subsequently selected for further analyses (questions 2, 3, 4 and 5 above). The exact age of the of old nests is unknown, since they can remain fairly intact for at least ten years. Active territories were delineated by mapping resident crows in March and early April, and the nest itself was usually found by listening for incubating females begging for food. Data from active nests of the year were used to address questions 1,6 , and 7 above.

Nest site characteristics were studied in June, when all chicks had left the nests. Nest trees were identified to species and the following measurements were taken: (1) nest height, (2) canopy cover in a $10 \mathrm{~m}$ radius from the nest tree's trunk (estimated in \%), (3) all trees (defined as woody plants more than $5 \mathrm{~m}$ tall) within a $10 \mathrm{~m}$ radius from the nest tree were counted and identified, (4) all bushes (defined as woody plants less than $5 \mathrm{~m}$ tall) within a radius of $10 \mathrm{~m}$ from the nest tree were counted, and (5) the cardinal direction of each nest in relation to the trunk. Further nest data were obtained from maps: (6) distance to the nearest inhabited building, (7) distance to nearest forest edge, and (8) distance to nearest active Hooded Crow nest.

\section{Breeding success}

Active nests were visited daily from 28 April to 7 May to record hatching date, which was noted as the first day on which the parent birds were seen feeding chicks or flying to and from the nest very often. Chicks were expected to leave the nest four to five weeks after hatching. Hence, active nests were observed for about an hour each day 26 May9 June, and the number of chicks were counted both before and after they had left the nest.

\section{Results}

\section{Breeding habitat and density}

Thirty-eight of 40 nests (29 old and 11 nests of the year) were located in forest habitat, and the remaining two were in garden trees. Eleven active nests were found in 2009, in other words 3.06 territories/ $\mathrm{km}^{2}$ land area, and 7.33 territories $/ \mathrm{km}^{2}$ forest. Distance to the nearest active Hooded Crow nest averaged $234.5 \mathrm{~m}(\mathrm{SD}=170 \mathrm{~m}$, range $110-564 \mathrm{~m}, \mathrm{~N}=11$ nests of the year).

\section{Nest site characteristics}

Mean tree density in the core of the nesting territories was 350 stems/hectare (mean per plot $=11, \mathrm{SD}=6.1$, range: $1-23, \mathrm{~N}=40$ (old nests and nests of the year pooled)). Mean density of bushes was $1487 /$ hectare (mean per plot $=46, \mathrm{SD}=34$, range $1-128, \mathrm{~N}=40$ ). Canopy cover averaged $8 \%$ $(\mathrm{SD}=5.6$, range $=1-25, \mathrm{~N}=40)$. To the human eye the typical breeding territory is thus a fairly open forest (Figure 1), but the variation in understorey cover is large.

Most nests were within $10 \mathrm{~m}$ of a forest edge, but variation was large (mean $=19 \mathrm{~m}, \mathrm{SD}=22$, range $=0-100, N=40$ (old nests and nests of the year pooled), Figure 2). For natural reasons in this study area, most nests were situated within $100 \mathrm{~m}$ of a building, but many were within only $40 \mathrm{~m}$, and a few were instead quite distant (mean $=68.4 \mathrm{~m}$, $\mathrm{SD}=114$, range $=5-472, \mathrm{~N}=40$, Figure 3 ).

All 40 nests were in a pine tree, and they were often placed near the top (mean height $=10.6 \mathrm{~m}$, $\mathrm{SD}=1.9$, range $=7--16, \mathrm{~N}=40$ (old nests and nests of the year pooled)). Nests were in all cardinal direc- 


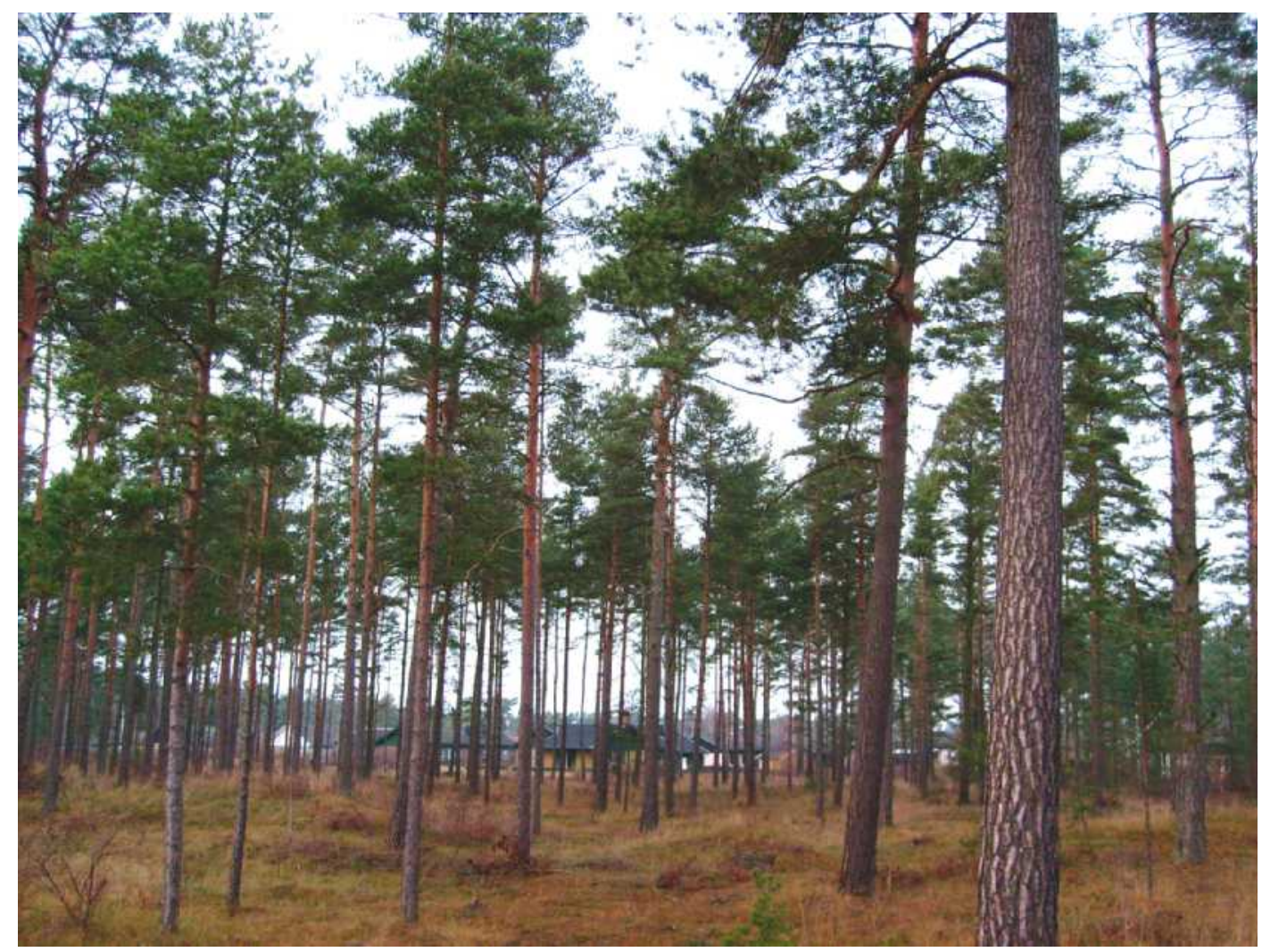

Figure 1. Typical nesting habitat of Hooded Crow Corvus corone cornix in Åhus, Scania. Photo: Rebecca Hessel. Typisk häckningsbiotop för gråkråka Corvus corone cornix i Ảhus, Skåne. Foto: Rebecca Hessel.

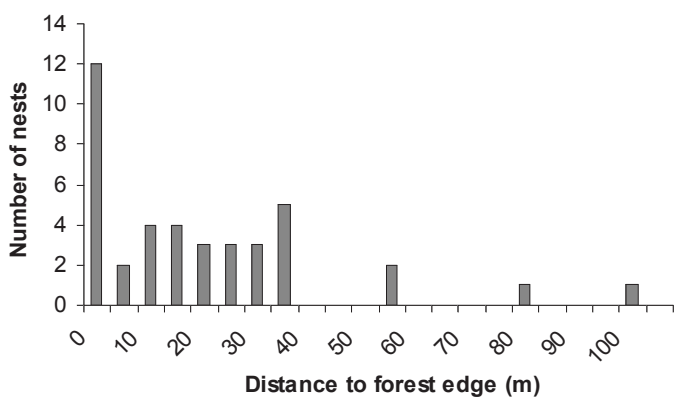

Figure 2. Distance from nests of Hooded Crows to nearest forest edge $(\mathrm{N}=40)$.

Avstånd från bon av gråkråka till närmaste skogskant $(N=40)$.

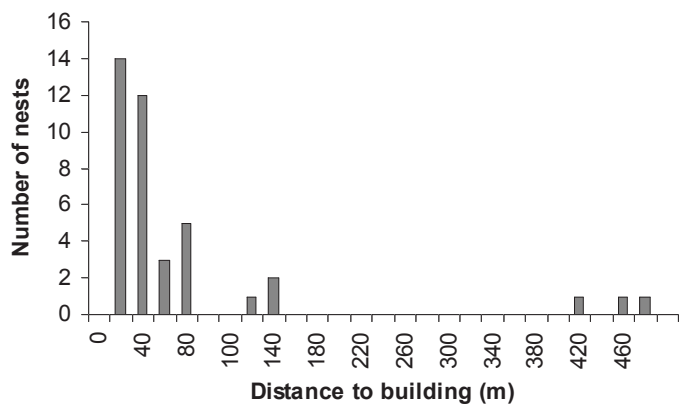

Figure 3. Distance from nests of Hooded Crows to the nearest building $(\mathrm{N}=40)$.

Avstånd från bon av gråkråka till närmaste byggnad $(N=40)$. 
tions, but significantly biased towards south-facing placement $(\mathrm{N}=1, \mathrm{E}=7, \mathrm{~S}=18, \mathrm{~W}=5 ; 9$ nests were centred in the tree; $\mathrm{Chi}^{2}=20.49, \mathrm{df}=3, \mathrm{P}<0.001$ ).

\section{Breeding success}

Ten out of eleven pairs hatched their brood successfully. The reason why one brood failed could not be determined. Most broods hatched between 28 April and 7 May, and there was no clear hatching peak (mean $=6$ May, $\mathrm{N}=10$ broods). Two broods were a bit late, hatching approximately 14 May. Chicks left the nests between 26 May and 9 June, with a clear peak in the end of this period (mean $=5$ June, $\mathrm{N}=7$ broods).

Thirty-six per cent of the pairs did not produce any fledglings in 2009 (one brood of eleven did not hatch, three more did not fledge any chicks). No pair fledged more than two chicks. The number of fledglings per pair hatching their eggs averaged $1.2(\mathrm{SD}=0.98, \mathrm{~N}=7)$. The number of fledglings per nest correlated negatively with distance to the nearest active crow nest, that is, breeding success was higher when the nearest next pair was close $\left(\mathrm{r}_{\mathrm{s}}=0.68, \mathrm{P}=0.02, \mathrm{~N}=11\right)$. However, fledgling number per nest did not correlate with nest height, understorey cover (density of bushes), distance to nearest building, or distance to forest edge (Spearman's rank correlations: $\mathrm{P}=0.43, \mathrm{P}=0.23, \mathrm{P}=0.19$, and $\mathrm{P}=0.14$, respectively). The variation in stem density (trees) and canopy cover at the nest trees was not large enough to make a correlation analysis meaningful.

\section{Discussion}

\section{Breeding habitat and density}

The density of breeding Hooded Crows in the study area was very high compared with national averages, and high also compared with typical values for agricultural landscapes in southern Sweden (e.g. national means of $0.1-0.3$ pairs $/ \mathrm{km}^{2}$ and regional means of up to $1.1-1.4$ pairs $/ \mathrm{km}^{2}$; Ottosson et al., in prep). Our interpretation is that the study area offers exceptionally good conditions for breeding Hooded Crows. We think this is due to a combination of many available nest sites and plentiful food on the one side, and possibly to low densities of predators on the other (cf. Andrén 1992). The latter two factors can be related to anthropogenic influence. Although fragmentation is not straightforward to quantify, we argue that the study area may have a farmland-forest edge-to-area ratio that is favorable for breeding Hooded Crows (cf.
Smedshaug et al. 2002). Although some studies from other countries report densities approaching ours (e.g. ca. 2.0-2.6 pairs $/ \mathrm{km}^{2}$; Hewson \& Leitch 1982, Myrberget 1982, Parker 1985), even higher values have been reported from Italy (6.7 pairs/ $\mathrm{km}^{2}$; Baglioni, Pieri \& Bogliani 1994) and Norway (6.8 pairs $/ \mathrm{km}^{2}$; Munkejord et al. 1985). Nearestnest distance in our study was very similar to that found in southern Norway by Munkejord et al. (1985; 290-312 m), but noticeably shorter than in a nearby study area in southern Sweden (360-427 m; Loman 1975).

\section{Nest site characteristics}

Pine was the preferred nest tree in our study, although mature trees of several other species were available. This result compares well to some previous compilations (e.g. Tenovuo1963, Wittenberg 1968, Kulczycki 1973 in Cramp \& Simmons 1977), possibly reflecting that conifers provide better shelter than deciduous trees. However, spruce was not utilized in our study area although it does occur (cf. Munkejord et al. 1985), and neither was oak although it is a much used nest tree in other areas (e.g. Cramp \& Simmons 1977, Jollet 1985). Interestingly, Loman (1975) found that Hooded Crows in a study area not very far from ours utilized a variety of nest tree species; Alnus, Pinus, Betula and Picea were the most common species and they were utilized in fairly equal proportion.

Most nests in our study were very close to a forest edge (cf. Parker 1985). We interpret this as a strategy to have the chicks close to good foraging habitats, which are open ground rather than closed forest. Such placement must be an obvious advantage considering how frequently the chicks need to be fed. Indeed, during the chick-feeding period adults were most often seen foraging in fields and gardens.

\section{Breeding success}

Hatching success in the present study (>90\%) compares well to previous studies (e.g. $86 \%$ in Parker 1985), but the proportion of nests producing fledglings (64\%) was low (cf. Parker 1985). So was the number of fledglings per pair, regardless of whether this is calculated per laid clutch or per successful nest (e.g. 3.2 chicks per active nest in Parker 1985 and 1.5 in Munkejord et al. 1985). Interestingly, Loman (1980) found a difference in fledgling production between experienced pairs and first-time breeders (1.6/pair versus $0.7 /$ pair). 
In other words, the low overall reproductive output noted by us may reflect a general long-term decline in breeding success and/or result from our study population comprising many unexperienced firsttime breeders (i.e. a more demographic causality).

We found that the number of fledglings per nest increased with decreasing distance to the nearest conspecific nest. Though our sample is limited, it should be noted that Munkejord et al. (1985) obtained results pointing in the same direction in a study area with even higher densities than that in our. One of the authors ( $\mathrm{RH})$ observed that Hooded Crows in close-nesting pairs were reciprocally very tolerant, and they were not aggressive towards each other. On a few occasions they even seemingly "cooperated" to chase away Hooded Crows emanating from more distant territories. This lends further support to the idea that Hooded Crows inhabiting neighbouring territories increase each other's breeding success. This could be achieved intentionally by common defense against predators and by increasing each other's foraging success (Sonerud, Smedshaug \& Bråthen 2001), but also more indirectly by increasing each other's vigilance (cf. Canestrari, Marcos \& Baglione 2007).

\section{Conclusion}

Although hatching success was high and although we found a positive effect of nest density, mean fledgling production per nest was low compared to historical data. We argue that such low reproductive output in a high-density population raises some concerns, not the least because of the general population decline of the Hooded Crow in some countries. Further studies of the nesting biology of the species are thus called for, and they should ideally include data on clutch size and also address negative density-dependent effects.

\section{References}

Andrén, H. 1992. Corvid density and nest predation in relation to forest fragmentation: a landscape perspective. Ecology 73: 794-804.

Baglione, V., Pieri, M. \& Bogliani, G. 1994. Maladaptive adoptions in the hooded crow Corvus corone cornix. Avocetta 18: 147-149

Canestrari, D., Marcos, J. M. \& Bagleone, V. 2007. Reproductive success increases with group size in cooperative carrion crows, Corvus corone corone. Animal Behaviour 75: 403-416.

Cramp, S. \& Simons. K.E.L. (eds.) 1977. Birds of the Western Palearctic, Vol. 1. Oxford University Press, Oxford.

Glutz von Blotzheim, U. (ed.) 1990. Handbuch der Vögel
Mitteleuropas. Band 2 Anseriformes (2nd edition). AulaVerlag, Wiesbaden.

Finnish Museum of Natural History 2010. http://www.luomus.fi/ seurannat/ linjalaskenta/ artikkelit/ maalinnut/ index. htm\#lajit. Downloaded 30 September 2010.

Hagemeijer, E.J.M. \& Blair, M.J. (eds.) 1997. The EBCC atlas of European breeding birds: their distribution and abundance. T \& AD Poyser, London.

Hewson, R. \& Leitch, A. F. 1982. The spacing and density of Hooded Crow nests in Argyll (Strathclyde). Bird Study 29: 235-238.

Jollet, A. 1985. Nest sites and density of a population of carrion crows Corvus corone L. in the Limousin region, central France. Alauda 63: 263-286.

Kulczycki, A. 1973. Nesting of members of the Corvidae in Poland. Acta Zoologica Cracoviensis 18: 583-666

Loman, J. 1975. Nest distribution in a population of the Hooded Crow Corvus cornix. Ornis Scandinavica 6: 169-178.

Loman, J. 1980. Reproduction in a population of the hooded crow Corvus cornix. Holarctic Ecology 3: 26-35.

Munkejord, A., Hauge, F., Folkedal, S. \& Kvinnesland, A. 1985. Nest density, breeding habitat and reproductive output in a population of the Hooded Crow Corvus corone cornix on Karmøy, SW Norway. Fauna norvegica Series C. 8: $1-8$.

Myrberget, S. 1982. Hooded crows Corvus corone cornix on a small island. Fauna 35: 8-10.

Møller, A.P. 1983. Habitat selection, flocking and feeding behaviour of Hooded Crows Corvus corone. Ornis Fennica 60: 105-111.

Ottvall, R., Edenius, L., Elmberg, J., Engström, H., Green, M., Holmqvist, N., Lindström, Å., Pärt, T. \& Tjernberg, M. 2009. Population trends for Swedish breeding birds. Ornis Svecica 19: 117-192.

Parker, H. 1985. Breeding performance and aspects of habitat selection in sub-arctic hooded crows Corvus corone cornix. Fauna norvegica, Series C 8: 100-105.

Smedshaug, C.A, Lund, S.E., Brekke, A., Sonerud, G.A. \& Rafoss, T. 2002. The importance of the farmland-forest edge for area use of breeding Hooded Crows as revealed by radio telemetry. Ornis Fennica 79: 1-13.

Sonerud, G., Smedshaug, C.A. \& Bråthen, Ö. 2001. Ignorant hooded crows follow knowledgeable roost-mates to food: support for the information centre hypothesis. Proc. $R$. Soc. Lond. B. 268: 827-831.

Tenevou, R. 1963. Zur brutzeitlichen Biologie der Nebelkrähe (Corvus corone cornix L.) in äusseren Schärenhof Finnlands. Annales Zoologici Societas Vanamo 25: 1-247.

Wittenberg, J. 1968. Freilanduntersuchungen zur Brutbiologie und Verhalten Rabenkrahe (Corvus c. corone). Zool. Ib. Syst. 95: 16-146

Zduniak, P. \& Antczak, M. 2003. Repeatability and withinclutch variation in egg dimensions in a Hooded Crow Corvus corone cornix population. Biological Letters 40: $37-42$.

\section{Sammanfattning}

Gråkråkan är en vanlig häckfågel över stora delar av Europa, men trots att den tidigare studerats flitigt finns ytterst lite publicerat om dess häck- 
ningsbiologi i den vetenskapliga litteraturen från de senaste årtiondena. Mot bakgrund av detta och det faktum att arten minskat i bland annat Sverige på senare tid valde vi ut ett $3,6 \mathrm{~km}^{2}$ stort område i jordbruksbygd i nordöstra Skåne för en häckningsbiologisk studie. Det undersökta området i utkanten av Åhus tätort utgörs till $1 \mathrm{~km}^{2}$ av bebyggelse och trädgårdar, $1 \mathrm{~km}^{2}$ trädlös sandstäpp och 1,6 $\mathrm{km}^{2}$ planterad tallskog. Trädgårdarnas växtlighet är synnerligen varierad medan den planterade tallskogen har inslag av gran, björk, rönn, ek, bok och poppel. Denna artikel bygger på data från 40 bon av gråkråka, funna under upprepade linjetaxeringar med 50 meters intervall av all trädbevuxen mark i området. Tjugonio av bona var äldre (från 2008 eller tidigare), medan 11 var under 2009 aktiva bon som studerades mer intensivt (3,06 aktiva bon (revir) per $\mathrm{km}^{2}$ landyta och 7,33 bon (revir) per $\mathrm{km}^{2}$ skogsklädd yta).

Allmänna karaktäristika baserade på gamla och aktiva bon $(\mathrm{N}=40)$ var följande. Alla bon låg $\mathrm{i}$ träd, varav 38 i skog och två i villaträdgårdar. Stamtätheten av träd i provytor $\left(314 \mathrm{~m}^{2}\right)$ med boträden som centrum var i medeltal 350/ha, det vill säga 11 (1-23) stammar per provyta. Motsvarande täthet av buskar var 1487 stammar/ha, det vill säga 46 (1-128) per provyta. Krontäckningen var i genomsnitt $8 \%(1-25 \%)$ och de flesta bon låg inom $10 \mathrm{~m}$ (medeltal 19 m (0-100); Figur 2) från en skogskant. Av naturliga skäl i detta studieområde låg de flesta bon ganska nära byggnader, men variationen var stor (medeltal 68 m (5-472); Figur 3). Alla bon låg i tallar, trots att mogna träd av andra arter fanns att tillgå i området. I förhållande till boträdens stam var bona placerade i alla väderstreck, men med en signifikant koncentration till söder $(\mathrm{N}=1, \mathrm{O}=7$, $\mathrm{S}=18, \mathrm{~V}=5,9$ centerade bon)

De elva aktiva bona låg i medeltal $234,5 \mathrm{~m}$ (110-564) från närmsta andra bo av gråkråka. Tio av elva par som skred till häckning kläckte sin kull, vilket inföll mellan 28 april och 14 maj (medeltal 6 maj, ingen tydlig topp). Sju av tio kläckta kullar producerade flygga ungar. De senare lämnade boet mellan 26 maj och 9 juni, med en tydlig topp i slutet av denna period (medeltal 5 juni). De sju flygga kullarna bestod alla av en eller två ungar (medeltal 1,2). Antalet flygga ungar per bo visade ett signifikant samband med avståndet till närmsta kråkbo, så att framgången var högre när närmsta kråkbo låg nära.

Revirtätheten i det undersökta området är mycket hög efter generella svenska förhållanden, och hög även för jordbruksbygd i Sydsverige. Vi tror att detta kan bero på god tillgång på föda i kombination med låga tätheter av predatorer på vuxna kråkor. Kläckningsfrekvensen $(96 \%, 10$ av 11 kullar) är i nivå med tidigare studier, men antalet bon som producerade flygga ungar (64\%) var lägre än i många andra studier. Detta gäller också antalet flygga ungar per par. Orsaken till den funna låga ungproduktionen är inte känd, men kan tjäna som ett observandum med tanke på artens generella minskning i Sverige. 